\title{
The Implementation of Creative Learning Models in Teaching Writing in Junior High School
}

\author{
Esti Kurniasih $^{1^{*}}$, Lina Purwaning Hartanti ${ }^{2}$ \\ ${ }^{1,2}$ Universitas Negeri Surabaya, Surabaya, Indonesia \\ *Corresponding Author: estikurniasih@unesa.ac.id
}

\begin{abstract}
Creative learning is a learning process that requires teachers to motivate and bring up the students creativity, both in the context of creative thinking and in the context of creative in doing things during the learning process, using a variety of learning methods and strategies, such as group work, problem solving, and so on. In line with creative learning, this study further aims to describe the development of learning devices (i.e. $R P P$ ) and the implementation of learning activities that use creative learning models in teaching writing skill in Junior high School. Based on the results of data analysis, it can be concluded that most of the RPPs developed had included all the components of $R P P$ in detail, start from school identity to the assessment. While related to the implementation of learning activities that use creative learning models in teaching writing, it can be concluded that the implementation had applied creative learning models in three learning activities, they are pre, whilst, and post activities.
\end{abstract}

Keywords: learning models, creative learning, writing skill.

\section{INTRODUCTION}

In learning a language, receptive skills (listening and reading skills) always precede productive skills (speaking and writing). This means that students must be able to understand what language is before they use it in oral/written communication. Dealing with writing skill, many students still encounter difficulties when they start to write. Such difficulties are those related to having no ideas in writing, unable to develop the outline and use the appropriate words and language use in their writing, and getting confused in understanding the text structure of their writing. In addition, the boring and monotonous teaching methods applied by the teacher in teaching writing also make students reluctant to write. To cope with these difficulties, teacher needs to strive for a learning model that is more interesting and preferred by students. Besides, the classroom atmosphere needs to be planned and constructed in such a way by applying the appropriate learning model so that students can be more active in participating and thinking critically during the learning process. This is in line with the Government Regulation No. 19 of 2005 which states that learning process in any school levels should be conducted in an inspiring, fun, and challenging manner so that students can be actively involved during the learning process.

In line with this Regulation, teachers are suggested to apply various interesting and creative learning models that are appropriate with their students' level and needs in their teaching. Creative learning is a learning process that requires the teachers to motivate and bring up the students creativity, both in the context of creative thinking and in the context of creative in doing things during the learning process, using a variety of learning methods and strategies, such as group work, problem solving, project-based, and so on. In applying those creative 
learning models, first of all, teachers should develop lesson plan that supports those learning models.

Related to the implementation of those creative learning models, therefore, this study was finally conducted in order to investigate more on (1) How learning devices (i.e. $R P P$ ) that use creative learning models in teaching writing skill in Junior high School are developed by PPG-SM3T students of English Education Study Program? and (2) How learning activities that employ creative learning models in teaching writing skill in Junior high School are implemented by PPG-SM3T students of English Education Study Program.

\section{LEARNING MODELS}

Teachers are professional educators who are responsible for educating, teaching, guiding, directing, training, assessing, and evaluating students in either primary or secondary education (Government Regulation no.74 of 2008). Marsh (1996, p. 10) said that teachers must have such professional competencies in teaching as motivating students, designing learning models, managing classes, designing learning process/activities, and evaluating the learning process. As a professional educator, in teaching teachers must be able to select and choose the right learning model for their students. In choosing a learning model, the teacher must pay attention to the students' condition, the available instructional materials and learning resources so it can be applied effectively and finally, supports the success of students' achievement.

Learning model can be defined as a systematic procedure of organizing learning experiences to achieve learning goals. Dahlan (1990) considers learning model as a plan for setting the curriculum, developing the instructional materials and guiding the teachers in delivering the materials. While Trianto (2007, p. 1) defines the learning model as a plan used for guiding the teachers in planning and designing the course. From those definitions, it can be concluded that learning models deal with the ways in which learning environments and instructional experiences can be constructed, sequenced or delivered.

\section{CREATIVE LEARNING MODELS}

As stated previously, creative learning is a learning process that requires the teachers to motivate and bring up the students creativity, both in the context of creative thinking and in the context of creative in doing things during the learning process, using a variety of learning methods and strategies, such as group work, problem solving, project-based, and so on.

To conduct creative learning models, there are several things that teachers need to take into account, those are: (1) teachers need to give the students freedom to develop new ideas, insight and knowledge; (2) teachers should be respectful towards students' opinions and ideas; (3) teachers need to give appraisal to students; (4) teachers should emphasize more on process rather than product assessment; (5) teachers should give the students opportunity to think critically and create; and (6) teachers should be able to bring up the students creativity through such questions as "Why, How, and What will happen if ...." instead of questions like "What" and "When" (Indrawati \& Setiawan, 2009).

Related to learning models, numerous interesting and creative learning models are developed, they are project based learning, discovery learning, problem-based learning, cooperative learning, scientific approach, genre based approach, etc.

Project based learning is a comprehensible instructional model that engages learners in such complex activities as choosing the topic for their project, searching for resources for needed information, organizing those resources, developing the project, combining the contributions of the group, solving the problems, creating the rubric for the assessment, 
presenting/sharing the project with other groups, obtaining the feedback, and doing group reflection toward the project. Project based learning offers many advantages and challenges when it is implemented in the classroom, they are increasing motivation, problem-solving ability, media research skills, collaboration, and resource management skills (Bransford \& Stein, 1993).

Another creative learning model, i.e. discovery learning, is a learning method that encourages students to ask questions and make a conclusion from the general principles of practical examples of experience (Bruner, 1961). Bruner further adds that discovery learning is a learning that is student oriented and aims to change the passive learning conditions into active and creative. In discovery learning, students are free to work in a learning environment with little or no guidance; they find their own information.

Problem-based learning (PBL) is a teaching method characterized by critical problems and problem-solving skills, and acquires knowledge. In PBL, students are actively engaged in learning content, strategies, and self-directed learning skills through collaboratively solving problems, reflecting on their experiences, and engaging in self-directed inquiry. The role of the teacher is to facilitate the students' learning by providing opportunities for learners to engage in constructive processing. The students take responsibility for their own learning and for the collective progress of their collaborative group.

Cooperative learning is a method of instruction that organizes classroom instruction so that groups of 2-6 students work together to reach a common goal. Cooperative learning involves all group members who share in process, content, and accountability. In cooperative learning, all group members are responsible not only for learning what is taught but also for helping teammates learn, thus creating an atmosphere of achievement. In other words, in cooperative learning the group is said to be successful if every member of the group is also successful. Brown \& Ciuffetelli (2009) discuss the five basic and essential elements to cooperative learning, they are positive interdependence, face-to-face promotive interaction, individual accountability, social skills, and group processing.

Scientific approach is a learning process designed in such a way that learners actively construct concepts, laws or principles through observing stages (to identify or find problems), formulating problems, proposing or formulating hypotheses, collecting data with various techniques, analyzing data (reasoning), drawing conclusions and communicating concepts, laws or principles found (Hosnan, 2014). Scientific approach comprises several activities such as observing (identifying something), questioning (and formulating hypotheses), experimenting/collecting data (information) within many kinds of techniques, associating/analyzing/processing data (information), drawing conclusion and also communicating the result of learning which comprises getting knowledge, skill and behavior (Ministry of Education and Culture, 2013).

Genre is primarily recognized by its communicative purpose, which shapes how a text is realized. Texts that belong to a genre share similar characteristics, such as target audience, organization of ideas and language choices (Swales, 1990). There are four stages in GenreBased Approach, they are Building knowledge of the field (BKOF), Modelling of the Text (MOT), Joint Construction of the Text (JCOT), and Independent Construction of the Text (ICOT). 


\section{CURRICULUM}

\section{ENGLISH SUBJECT IN JUNIOR HIGH SCHOOL}

2013 Curriculum is the replacement of the previous curriculum (2006 Curriculum/Kurikulum Tingkat Satuan Pendidikan). This curriculum is communicative and competency-based where students can apply various kinds of competencies in their daily life. There are two main components in 2013 Curriculum: Core Competencies (Kompetensi Inti/KI) and Basic Competencies (Kompetensi Dasar/KD). Core competence is the level of ability to achieve Graduate Competency Standards (Standar Kompetensi Lulusan/SKL) that a student must have at each grade level. Core competencies in 2013 Curriculum consist of spiritual behaviour/manner, social manner/attitudes, knowledge, and skills. While Basic Competence is the minimum ability that must be achieved by students for a certain subject in each educational level. The Basic Competence of English in junior high school includes identifying social functions, text structure, and language features of several text types (KD 3) and getting the text meaning and constructing/writing a text (KD 4).

\section{TEACHING PREPARATION}

Teaching Preparation is a must for teachers. It is a guide for teachers during the teaching and learning process. There are several components of teaching preparation, two of them are syllabus and lesson plan (Permendikbud No. 22/2016).

Syllabus is the first component of teaching preparation that should be prepared before developing lesson plan. Based on Permendikbud No. 22/2016, syllabus is developed based on Graduate Competency Standards (Standar Kompetensi Lulusan/SKL) and Content Standards (Standar Isi/SI) for elementary and secondary education units according to the learning patterns in each particular academic year. It is used as a reference for teachers to prepare the teaching frameworks for each learning subject. Syllabus contains at least school identity, subject/course identity, Core Competencies (Kompetensi Inti/KI), Basic Competencies (Kompetensi $\operatorname{Dasar} / K D)$, theme (especially for elementary school), learning materials, learning activities, assessment, time allocation, and learning sources.

Another component of teaching preparation, namely lesson plan or Rencana Pelaksanaan Pembelajaran ( $R P P$ ) is very crucial thing in teaching-learning process since the success or failure of teaching-learning activities is influenced by teacher's lesson plan. It is an instructional plan developed by the teacher by referring to syllabus and can be conducted in one or more meetings. Brown (1994, pp. 396-398) said that lesson plan consists of some important components, those are: learning objectives, materials and learning sources, learning activity procedures, evaluation, and task. While according to Tyler in Richard and Renandya (2002, p. 31), designing a lesson plan takes four steps, those are: formulating the learning objectives, selecting the teaching and learning materials, organizing the teaching and learning activities, and applying the right assessment. Further, Ministerial Decree (Permendikbud No. 22/2016) states that components of a lesson plan comprise school identity, subject/course identity, grade/semester, theme/sub theme, time allocation, Core Competencies (KI), Basic Competencies $(K D)$, indicators, learning objectives, learning materials, learning methods/techniques, learning media, learning sources, learning activities, and assessment. 


\section{REAL TEACHING PRACTICE}

Real teaching practice is the implementation of lesson plan. Based on Permendikbud No. $22 / 2016$, there are three activities that should be done by the teacher when he or she performs the real teaching practice; and those activities should be in line with his or her lesson plan. Those activities are pre-activities or opening, whilst activities, and post activities or closing.

In pre-activity or opening stage, teachers need to prepare the students psychologically and physically to join the learning process; ask them some questions related to the previous learning materials and connect them with the learning materials they are going to learn, tell them the learning objectives they are going to achieve, and give them brainstorming activity.

Meanwhile, whilst activity is the core of learning process where teachers can apply various creative learning models, such as project based learning, discovery learning, problembased learning, cooperative learning, scientific approach, genre based approach, etc. In implementing those learning models teachers can make use of learning materials, media and resources which are attractive and appropriate with the students' characters and the learning models selected.

In post activities or closing, both the teacher and students, individually or in group review the lesson, give reflection and feedback towards the lesson, do such follow-up activities as remedial teaching, enrichment, quiz or test, and announce the next topic/goal of the learning materials for the upcoming meeting.

\section{WRITING SKILL}

Writing is a process of expressing ideas and thoughts by putting them into a good arrangement in the written form. In line with this, Meyers (2005) states that writing is an action; a process of discovering and organizing ideas, putting them on paper, editing or reshaping and revising them. Writing is not a simple activity that could be done in a spontaneous way, yet writing is a complex process that requires efforts. The complex process of writing requires the writers to process and develop the ideas, arrange them appropriately, use proper punctuation mark in written text, choose appropriate grammar, and produce a good final writing product. Brown (1994, p. 335) states that writing is an activity that involves the process of thinking, drafting, and revising. It means that before releasing the writing product, it should be planned first and revised repeatedly. Another expert, Hammer (cited in Richard \& Renandya, 2002, p. 303) proposes four stages of writing process. Those are planning, drafting, revising and final drafting/editing. Planning is when the students are encouraged to plan what they are going to write. Then the students will move to the second stage that is drafting. Here, the students focus on their writing fluency related to the grammatical structure and writing accuracy. After that, in revising stage, the students will rewrite and correct their writing after getting feedback. In the last stage which is final drafting/editing, the students are required to fix up their text according to the last justification of their final draft of writing project. Hammer's idea is also supported by Hague (2003) who said that writing is a process of creating, organizing, writing, and polishing or editing. Meanwhile, Gebhard (2000, p. 226) and Boas (2011) also mention three stages in writing, those are prewriting (planning), drafting (writing draft), and revising. From those experts' opinions and ideas about process of writing, it is clear that writing is not an easy skill and takes a long time. It is not easy because it demands the students to have regular practice in writing in order to be competent writer; and it takes a long time since it consists of such stages as proposed by those experts above. To produce a good writing, some components of writing are involved, they are: organization, content, vocabulary, language use, and 
mechanics (Heaton, 2006, p. 146; Jacobs, et al., 1981). These five components become the focus with which writing should be evaluated. Each component has their own grade or score which determines the score of writing. The better the score, the better the writing is.

Writing is very important skill to be learned. Through writing, one can inform others, carry out transactions, persuade, infuriate, tell others how he/she feels, learn to shape his or her thoughts and ideas, etc. Writing is also considered as an activity that is closely related with real life condition, since it is needed in social, work or study situations. Even nowadays, writing becomes a very important skill to face the global era. This means that writing is now used widely in every aspect of life, particularly for communicating with people, either in formal or in informal writing. Thus, learning writing especially for students is very important for them as the input to face the future.

Seeing the importance of writing, particularly as one of the communication tools, it is not surprising that it is given from the early stages. In our country, it is given from elementary school (writing a sentence/sentences) to university level (writing essays, articles, and papers). Even in junior and senior high schools, writing is emphasized and taught in many different text types, such as narrative, recount, descriptive, report, procedure, reviews, news item, etc. Besides, as stated in 2013 English Curriculum, literacy approach where knowledge about the language and how to use it for real communication (oral and written communication) is also emphasized.

Even though the teaching of writing skill has been given to the students from the early stages, there are many students who still encounter a lot of problems in expressing their ideas into the written language. Those problems deal directly with their inability to combine and link the sentences into a good and coherent paragraph/essay. In addition, problem related to content - what to say and being lost for ideas is a common experience to most students, especially when they are required to write. To cope with those problems above, the teacher needs to be aware that writing is an important, basic language skill and needs to be taught in interesting and creative ways. Besides, he or she should also phase the writing tasks from the simplest to more complex stage so that students are not frustrated with writing skill.

\section{METHOD}

Since this study aims at investigating and describing the development of learning devices (i.e. $R P P)$ and the implementation of learning activities that use creative learning models in teaching writing skill in Junior high School, descriptive qualitative research is an appropriate design used in this study. Qualitative research more focuses on the process rather than outcomes of the phenomena. It provides descriptive accounts targeted to understanding a phenomenon using data that might be collected in a variety of ways. The purpose is to understand the world or experience of another (Ary, Jacobs, Razavieh, \& Sorensen, 2010). Wiersma (2000) also adds that descriptive research is a research that describes the condition of a phenomenon in a particular time. The subjects of this study are the PPG-SM3T students of English Education Study Program at Unesa, while the objects of this study are the learning devices (i.e. RPP) developed by PPG-SM3T students of English Education Study Program at Unesa. The data in this study are the results of learning devices (i.e. $R P P$ ) developed by PPG-SM3T students of English Education Study Program that use creative learning models in teaching writing skill in Junior high School and the teacher and students' activities during the learning process of teaching writing that uses creative learning models. To collect those data, the researchers did some procedures: (1) read and analyzed the RPP using RPP analysis rubric; (2) observed the teacher and students' activities during the learning process of teaching writing that uses creative 
learning models; (3) wrote the teacher and students' activities during the learning process of teaching writing in the field notes while observing; (4) analyzed the learning process / activities of teaching writing that employ creative learning models using learning process assessment rubric; and (5) reported and presented the results of the data analysis in the form of words (narration) and tables.

\section{FINDINGS AND DISCUSSION}

\section{THE DEVELOPMENT OF LEARNING DEVICES THAT USE CREATIVE LEARNING MODELS IN TEACHING WRITING SKILL IN JUNIOR HIGH SCHOOL}

As previously mentioned in the research objectives, this study aims to describe the development of learning devices (i.e. $R P P$ ) and the implementation of learning activities that use creative learning models in teaching writing skill in Junior high School. Further, in this study the researchers focused on the eighth grade of junior high school. There are three Basic Competencies $(K D)$ described in this study, namely constructing texts in the form of (1) greeting card, (2) recount, and (3) short message (memo), short and simple announcement, and notice.

There are four lesson plans $(R P P)$ that will be analyzed in this study. These RPPs are representatives of the lesson plans that use creative learning models which will be applied in teaching writing skill in junior high school, especially at the eighth grade. Those RPPs were then analyzed using $R P P$ analysis rubric. This instrument was formulated and determined by the Central PPG team (Curriculum Centre, Directorate of Higher Education).

As stated in the $R P P$ analysis rubric, there are seven components of $R P P$ that must be analyzed, they are: (1) learning objectives; (2) learning materials; (3) learning strategies/models; (4) learning media; (5) learning sources; (6) evaluation/assessment; and (7) remedial/enrichment activities. Each of these components includes indicators and descriptors. Below are the results of the development of learning devices (i.e. $R P P$ ) that use creative learning models in teaching writing skill in Junior high School.

\section{RPP 1\#}

The basic competence of writing skill in RPP $1 \#$ is to construct/write a special text in the form of short and simple greeting card related to special days. RPP $1 \#$ had included all components of $R P P$ in detail, starting from school identity to remedial teaching and enrichment.

In the indicator section (i.e. Indikator Pencapaian Kompetensi/IPK), RPP 1\# stated its $I P K$ clearly by using operational verbs. In the learning objective, the four components of learning objective (namely Audience, Behavior, Condition, and Degree) were mentioned completely and clearly. Besides, the other components like learning materials, learning media, learning sources, remedial teaching, and enrichment were also clearly explained. Then, in the learning method component, RPP 1\# used Genre Based Approach (GBA) which consists of four stages applied in the learning activities, they are Building Knowledge of the Field (BKOF), Modelling of the Text (MOT), Joint Construction of the Text (JCOT), and Independent Construction of the Text (ICOT). In the assessment component, RPP I\# had mentioned the techniques and the forms of assessment, time of execution, grids, questions, and also the rubric in detail and clearly. 


\section{RPP 2\#}

The basic competence of writing skill in $R P P 2 \#$ is to construct/write a short and simple spoken and written recount text, which is related to the personal experience in the past (personal recount). RPP 2\# had included most of the RPP components in detail and clearly, starting from school identity to the assessment. There were two components which were not mentioned in $R P P$ 2\#, namely the components of remedial teaching and enrichment. In the IPK component, $R P P$ 2\# had formulated its $I P K$ clearly by using operational verbs. In the learning objective component, the four components of learning objective (i.e. Audience, Behavior, Condition, and Degree) were mentioned completely and clearly. Other components like learning materials, learning media, learning sources were clearly described too. In the learning method component, RPP 2\# used a Scientific Approach which consists of five stages applied in the learning activities. Those stages are observing, questioning, experimenting/collecting information, associating, and communicating. In the assessment part, $R P P 2 \#$ only mentioned the assessment guidelines (rubric). While the techniques and the forms of assessment, time of execution, and also grid were not explicitly and clearly stated.

\section{RPP 3\#}

The basic competence of writing skill in RPP $3 \#$ is to construct/write short and simple special texts in the form of short messages (memo), announcement, and notice, which are related to school activity. $R P P 3 \#$ had stated some $R P P$ components, starting from school identity to the assessment. However, there were three components which were not mentioned in $R P P 3 \#$, those were learning objectives, remedial teaching, and enrichment. In the IPK component, $R P P$ $3 \#$ had stated its $I P K$ vividly by using operational verbs. Other components like learning materials, learning media, and learning sources were also clearly described. In the learning method component, RPP 3\# used a scientific approach which covers five steps applied in the leaning activities, namely observing, questioning, experimenting/collecting information, associating, and communicating. In the assessment part, $R P P 3 \#$ only mentioned the rubric. While the techniques and the forms of assessment, the timing of the assessment, and the grading assessment were not explicitly and clearly stated.

\section{RPP 4\#}

The basic competence of writing skill in RPP 4\# is to construct/write short and simple special texts in the form of short message (memo), announcement, and notice, which are related to school activity. RPP 4\# had stated most of the RPP components, starting from school identity to the assessment. However, there were two components which were not mentioned in RPP 4\#, they are components of remedial teaching and enrichment. Then, in the IPK component, $R P P$ $4 \#$ had stated its $I P K$ clearly by using operational verbs. In the learning objective, only three components of learning objective were mentioned, namely Audience, Behavior, and Condition; while the Degree component was not mentioned explicitly. However, the components of learning materials, learning media, and learning sources were described clearly. In the learning method, RPP 4\# used scientific approach which includes five stages applied in the learning activities, they are observing, questioning, experimenting/collecting information, associating, and communicating. In the assessment/evaluation part, RPP $4 \#$ had mentioned in detail and clearly the techniques and the forms of assessment, the grading assessment, questions, and also the rubric. 
From the results of the $R P P$ analysis, it can be concluded that most of the $R P P$ developed had included all $R P P$ components in detail and clearly, starting from school identity to the components of assessment. In the IPK component, all RPPs had formulated their IPK clearly by using operational verbs. Then, in the learning objective part, four components of learning objective (i.e. Audience, Behavior, Condition, and Degree) were mentioned completely and clearly. Besides, the other components like learning materials, learning media, and learning sources were also clearly explained. However, in the part of remedial teaching and enrichment, most of the RPPs did not explain these components. In the learning method part, each of the RPPs had used one method or approach such as Genre Based Approach (GBA) or Scientific Approach. In the assessment, most of the RPPs had clearly mentioned the techniques and the forms of assessment and the rubric.

\section{THE IMPLEMENTATION OF LEARNING ACTIVITIES THAT USE CREATIVE LEARNING MODELS IN TEACHING WRITING SKILL IN JUNIOR HIGH SCHOOL}

From the observation result on the implementation of learning processes/activities that use creative learning models in teaching writing skill in junior high school, it can be concluded that its implementation was delivered through the application of only one method, namely Scientific Approach or Genre Based Approach (GBA). Whatever the approach or method is applied, the process or learning activities on writing skill in junior high school include pre-activities, whilst activities, and post activities. The following is the result of the observation towards the implementation of learning processes or activities using creative learning models in teaching writing skill in the junior high school.

\section{RPP 1\#}

From the observation result, RPP 1\# was applied in the learning activities that used Genre Based Approach (GBA) which includes four stages, namely Building Knowledge of the Field (BKOF), Modelling of the Text (MOT), Joint Construction of the Text (JCOT), and Independent Construction of the Text (ICOT). In addition, below is the detailed implementation of the learning process/activities of writing skill in the classroom using $R P P$ 1\#.

a. Pre-Activities

In this activity, first, the teacher greeted the students and asked one of the students to lead the pray, then followed by checking the attendance and asking the students about some special days that were necessary to be celebrated. Next, the teacher explained the topic of the lesson and the learning objectives.

b. Whilst Activities

In this activity, through Genre Based Approach (GBA) which includes four stages namely Building Knowledge of the Field (BKOF), Modelling of the Text (MOT), Joint Construction of the Text (JCOT), and Independent Construction of the Text (ICOT), the teacher delivered greeting card materials clearly; implemented the concept of learning materials in the daily life; implemented active learning; enriched good habits during the learning process; used tools/materials, media and IT; managed the class conductively; used language clearly and easily understood by students; implemented the process and product assessment, showed empathy and care for students; and had an open attitude towards the students. 


\section{New Language Dimensions}

Journal of Literature, Linguistics, and Language Teaching

Volume 1 (1) 2020

https://journal.unesa.ac.id/index.php/nld/index

\section{c. Post Activities}

Before closing the teaching and learning process, both the teacher and the students reviewed the lesson. Besides, they also discussed some difficulties encountered by the students during the learning process and looked for the solution. At last, the teacher announced the next topic/goal of the learning materials for the upcoming meeting.

\section{RPP 2\#, RPP 3\#, AND RPP4\#}

From the result of the observation, $R P P$ 2\#, RPP 3\#, and $R P P$ 4\# were applied in the learning activities which used Scientific Approach comprising five stages, those are observing, questioning, experimenting/collecting information, associating, and communicating. Below is the implementation of learning process/activities in the writing skill class that used $R P P 2 \#$, RPP 3\#, and RPP 4\#.

\section{a. Pre-Activities}

In this activity, first, the teacher greeted the students and asked one of the students to lead the pray, then followed by checking the attendance, motivating the students to learn, giving brainstorming activity, and telling the students the topic of the lesson and the learning objectives.

b. Whilst Activities

In this activity, by using Scientific Approach that covers five stages, namely observing, questioning, experimenting/collecting information, associating, and communicating, the teacher delivered recount text materials (RPP 2\#), short messages (RPP 3\#), and announcement and notice (RPP 4\#) clearly and systematically. The teacher also implemented the concept of learning materials in the daily life; implemented active learning; enriched good habits during the learning process; used tools/materials, media and IT; managed the class conductively; used language clearly which was easily understood by students; implemented the process and product assessment, showed empathy and care for students; and had an open attitude towards the students.

\section{c. Post Activities}

Before closing the teaching and learning process, both the teacher and the students reviewed the lesson. Besides, they also discussed some difficulties encountered by the students during the learning process and looked for the solution (doing reflection). At last, the teacher announced the next topic or goal of the learning materials for the upcoming meeting.

From the observation results on the implementation of learning processes/activities using creative learning models in teaching writing skill in the classroom (junior high school), it can be concluded that its implementation was in line with Permendikbud No. 22/2016, that was delivered through three activities covering pre-activities, whilst activities, and post activities. Besides, teachers had also implemented creative learning models both in the context of creative thinking and in the context of creative in doing things. Further, the teacher had succeeded in applying creative learning models during the learning process where the teacher was able to motivate and bring out the creativity of students during the learning process by using various methods and strategies. For example, the teacher asked the students to do 
teamwork, give freedom to students for developing their ideas, knowledge, and thinking critically, and also to encourage students to be respectful towards the other students' ideas, etc.

\section{CONCLUSION}

From the analysis of $R P P$ development using creative learning models in teaching writing skill, it can be concluded that most of the RPPS developed had included all the components of $R P P$ in detail and clearly, starting from school identity to the assessment component. In addition, from the observation results on the implementation of learning processes/activities using creative learning models in teaching writing skill in the classroom, it can be concluded that its implementation was in line with Permendikbud No. 22/2016, that was delivered through three activities covering pre-activities, whilst activities, and post activities. Besides, teachers had also implemented creative learning models both in the context of creative thinking and in the context of creative in doing things.

\section{REFERENCES}

Ary, D., Jacobs, L. C., Razavieh, A., \& Sorensen, C. (2010). Introduction to Research in Education (Eighth Ed.). Belmont: Wadsworth Cengange Learning.

Boas, V. (2011). Process Writing and the Internet: Blogs and Ning Networks in the Classroom. Retrieved September 29, 2008, from http://English Teaching Forum Journal, 49(2), 2633.

Bransford, J.D. and Stein, B.S. (1993). The Ideal Problem Solver: A Guide for Improving Thinking, Learning, and Creativity. New York: freeman, Ltd.

Brown H. D. (1994). Principles of Language Learning and Teaching. $3^{\text {rd }}$ Edition. Englewood Cliffs, NJ: Prentice Hall Regents.

Brown, H., \& Ciuffetelli, D.C. (Eds.). (2009). Foundational Methods Understanding Teaching and Learning. Toronto: Pearson Education.

Bruner, J. S. (1961). The Act of Discovery. Harvard Educational Review.

Dahlan. (1990). Model-model Mengajar. Bandung: Diponegoro.

Gebhard, J.G. (2000). Teaching English as a Foreign or Second Language. Ann Arbor: The University of Michigan Press.

Hague, A. (2003). The Essentials of English. New York: Pearson, Inc.

Hosnan. (2014). Pendekatan Saintifik dan Kontekstual dalam Pembelajaran Abad 21. Bogor: Ghalia Indonesia.

Jacobs, H.L. et al. (1981). Testing ESL Composition: A Practical Approach. Rowley: Newbury House Publishers, Inc.

J.B Heaton. (2006). Writing English Language Tests. London: Longman, Ltd.

Indrawati and Setiawan, W. (2009). Pembelajaran Aktif, Kreatif, Efektif dan Menyenangkan untuk Guru SD. Jakarta: PPPPTK IPA.

Marsh, C. (1996). Handbook for Beginning Teachers. Sydney: Addison Wesley Longman Ltd.

Meyers, A. (2005). Gateways to Academic Writing: Effective Sentences, Paragraph, and Essays. New York: Longman.

Peraturan Menteri Pendidikan dan Kebudayaan (PERMENDIKBUD). (2016). Peraturan Menteri Pendidikan dan Kebudayaan Nomor 22 Tahun 2016 tentang Standar Proses Pendidikan Dasar dan Menengah. Jakarta: Permendikbud.

Richards, J. C. and W. A. Renandya. (eds.). (2002). Methodology in Language Teaching: An Anthology of Current Practice. Cambridge: Cambridge University. 


\section{New Language Dimensions}

Journal of Literature, Linguistics, and Language Teaching

Volume 1 (1) 2020

https://journal.unesa.ac.id/index.php/nld/index

Swales, J. (1990). Genre Analysis: English in Academic and Research Settings. Cambridge, UK: Cambridge University Press.

Trianto. (2007). Model-model Pembelajaran Inovatif Berorientasi Konstruktivistik. Jakarta: Prestasi Pustaka.

Wiersma, W. (2000). Research Methods in Education: An Introduction. New York: Pearson/Allyn and Bacon, Ltd 